\title{
Apolipoprotein(a) Gene Polymorphism in the Korean Population: Is There Any Relevance to Essential Hypertension?
}

\author{
Byung Yong Kanga J oon Seol Bae ${ }^{a}$ Ki Tae Kim ${ }^{a}$ J ae Hyoun Kim \\ J ung Hee Shin ${ }^{c}$ Chung Choo Leec \\ aSeoulin Bioscience Institute, Seoulin Bioscience Co. Ltd., b Department of Health Science, College of \\ Natural Science, Dongduk Women's University, 'School of Biological Science, Seoul National University, \\ Seoul, Korea
}

\author{
Key Words \\ Apolipoprotein(a) - Essential hypertension . \\ Polymorphism
}

\begin{abstract}
Objective: To investigate the role of the apolipoprotein(a) $[A p o(a)]$ gene in predicting essential hypertension in the Korean population, we undertook a case-control study using the TITTA repeat and the Met/Thr polymorphisms of the Apo(a) gene. Methods: The study subjects consisted of 74 essential hypertensives and 211 normotensive individuals. For polymorphism analysis, DNA was amplified by polymerase chain reaction (PCR). In the case of the Met/Thr polymorphism, amplified PCR products were digested with the restriction enzyme Kspl. Genotyping was performed by a $10 \%$ nondenaturing polyacrylamide gel. Results: There were no significant differences in the allele and genotype frequencies of these polymorphisms between normotensive and essential hypertensive subjects $(p>0.05)$. Furthermore, levels of lipoprotein(a) in the plasma were not significantly associated with the different genotypes of the
\end{abstract}

Apo(a) gene in either group $(p>0.05)$. Conclusion: The polymorphisms of these two loci on the Apo(a) gene are unlikely to contribute to the etiology of essential hypertension in the Korean population.

Copyright @2002 S. Karger AG, Basel

\section{Introduction}

Lipoprotein(a) $[\operatorname{Lp}(\mathrm{a})]$ is a plasma lipoprotein that includes a low-density lipoprotein component and a large glycoprotein, apolipoprotein(a) [apo(a)] [1]. Lp(a) was reported for the first time in 1963 by Berg [2], and the physiological role of this lipoprotein is still unclear. According to many epidemiological studies, high levels of plasma Lp(a) correlate with diverse cardiovascular diseases [3-7]. Therefore, this lipoprotein has been considered an independent risk factor for cardiovascular diseases. Furthermore, plasma Lp(a) levels are largely genetically determined, and over $90 \%$ of interindividual variation in this lipoprotein is due to sequence variation in the Apo (a) gene [8]. Among the remaining 10\%, it is estimated that variation of the kringle- 4 repeat number in the

\begin{tabular}{ll}
\hline KARGER & ( 2002 S. Karger AG, Basel \\
$1011-7571 / 02 / 0112-0069 \$ 18.50 / 0$ \\
$\begin{array}{l}\text { Fax +41613061234 } \\
\begin{array}{l}\text { E-Mail karger@karger.ch } \\
\text { www.karger.com }\end{array}\end{array}$ & $\begin{array}{l}\text { Accessible online at: } \\
\text { www.karger.com/journals/mpp }\end{array}$
\end{tabular}

Dr. Ki Tae Kim
Seoulin Bioscience Institute, Seoulin Bioscience Co. Ltd.
Seoulin Building, 452-2, Songnae-Dong
Gangdong-Gu, Seoul 134-030 (Korea)
Tel. +82 2478 8488, Fax +82 2479 0397, E-Mail ktkim@seoulin.co.kr 
Apo(a) gene may account for about $40-70 \%$ of interindividual differences in plasma $\mathrm{Lp}(\mathrm{a})$ levels [9]. In addition, the (TTTTA $)_{n}$ repeat polymorphism of the Apo(a) gene is likely to be one of the factors associated with the plasma $L p(a)$ level, and may account for $10-14 \%$ of interindividual differences in plasma Lp(a) levels in the Caucasian population [10]. In the case of the Asian population, Park et al. [11] reported that the (TTTTA) n repeat polymorphism has an effect on the serum Lp(a) level in the general Japanese population. However, these are only limited reports regarding the role of the $\operatorname{Apo}(a)$ gene in essential hypertension. Therefore, we investigated the relationship between the genetic poylmorphisms of the $A p o(a)$ gene and essential hypertension in the Korean population.

\section{Subjects and Methods}

\section{Subjects}

We collected 285 blood samples from outpatients of the Seoul Hygiene Hospital, Seoul, Korea. Seventy-four Korean individuals with essential hypertension were identified in this group, with blood pressure above $140 / 90 \mathrm{~mm} \mathrm{Hg}$, and the remaining 211 were normotensives. Of these, there was an equal number of males and females (91 each). The gender information for the remaining 29 persons was unavailable. The age and body mass indices were recorded.

\section{Biochemical Assays}

Blood samples were obtained in EDTA tubes from individuals who had been fasting for $12-16 \mathrm{~h}$. The plasma samples were separated within $30 \mathrm{~min}$ of collection by centrifugation at $2,000 \mathrm{~g}$ for $15 \mathrm{~min}$ at $4^{\circ} \mathrm{C}$, and aliquots of plasma were stored at $-70^{\circ} \mathrm{C}$ in deepfreeze. Plasma $\mathrm{Lp}$ (a) levels were measured by immunonephelometry within 2 weeks. Unfortunately, owing to a shortage of plasma samples, we could not measure the plasma $L p(a)$ levels for all samples studied.

\section{Genotyping}

Genomic DNA was prepared from the buffy coats of whole blood $(5 \mathrm{ml})$ after lysis of the red blood cells [12]. The polymerase chain reaction (PCR) primer sequences used to detect the (TTTTA) n $_{\text {repeat }}$ polymorphism of the Apo(a) gene are 5'-ATTTGCGGAAAGATTGATACTATGC-3' for the forward primer and 5'-CCAAAATCACGTCAGTGCACTTCAA-3' for the reverse primer [13]. PCR was performed in a final volume of $50 \mu \mathrm{l}(100 \mathrm{ng}$ of genomic DNA, 20 pmol of each primer, $200 \mu M$ each of the four dNTPs, $1.5 \mathrm{mM}$ $\mathrm{MgCl}_{2}, 50 \mathrm{~m} M \mathrm{KCl}$ and $10 \mathrm{~m} M$ Tris- $\mathrm{HCl}, \mathrm{pH} 8.4$, and 2.5 units of Taq DNA polymerase). The reactions were denatured at $96^{\circ} \mathrm{C}$ for $1 \mathrm{~min}$, annealed at $55^{\circ} \mathrm{C}$ for $1 \mathrm{~min}$ and extended at $70^{\circ} \mathrm{C}$ for $2 \mathrm{~min}$ over 30 cycles with a final extension time of $10 \mathrm{~min}$ at $72^{\circ} \mathrm{C}$. After PCR amplification, an aliquot $(5 \mu \mathrm{l})$ of each PCR product was loaded onto a $10 \%$ nondenaturing polyacrylamide gel. The band patterns were detected by silver staining.

The PCR primer sequences used to detect the Met/Thr polymorphism of the Apo (a) gene are 5'-CGATACAGGCCCTTGGTGTTTTACCG-3' for the forward primer and 5'-GCCCTAGGCTTG-
Table 1. Genotype and allele frequencies for the (TTTTA)n repeat polymorphism of the Apo(a) gene in normotensive and essential hypertensive subjects

a Genotype frequencies

\begin{tabular}{|c|c|c|c|c|}
\hline \multirow[t]{2}{*}{ Genotype } & \multicolumn{2}{|c|}{ Normotensive subjects } & \multicolumn{2}{|c|}{ Hypertensive subjects } \\
\hline & $\mathrm{n}$ & $\%$ & $\mathrm{n}$ & $\%$ \\
\hline $8 / 5$ & 10 & 5.2 & 4 & 5.9 \\
\hline $8 / 6$ & 1 & 0.5 & 0 & 0.0 \\
\hline $8 / 8$ & 107 & 56.0 & 44 & 64.7 \\
\hline $9 / 5$ & 1 & 0.5 & 0 & 0.0 \\
\hline $9 / 8$ & 58 & 30.4 & 16 & 23.5 \\
\hline $9 / 9$ & 9 & 4.7 & 3 & 4.4 \\
\hline $10 / 8$ & 9 & 2.1 & 0 & 0.0 \\
\hline $10 / 9$ & 1 & 0.5 & 1 & 1.5 \\
\hline Total & 191 & 100.0 & 68 & 100.0 \\
\hline
\end{tabular}

b Allele frequencies

\begin{tabular}{lrr}
\hline Allele & $\begin{array}{l}\text { Normotensive subjects } \\
\mathrm{n} \text { (frequency) }\end{array}$ & $\begin{array}{l}\text { Hypertensive subjects } \\
\mathrm{n} \text { (frequency) }\end{array}$ \\
\hline 5 & $11(0.0288)$ & $4(0.0294)$ \\
6 & $1(0.0026)$ & $0(0.0000)$ \\
8 & $287(0.7513)$ & $108(0.7941)$ \\
9 & $78(0.2042)$ & $23(0.1691)$ \\
10 & $5(0.0131)$ & $1(0.0074)$ \\
\hline Total & $382(1.0000)$ & $136(1.0000)$
\end{tabular}

There were no statistically significant differences in genotype and allele frequencies between normotensive and hypertensive subjects.

GAACCTGGATG-3' for the reverse primer [14]. PCR was performed in a final volume of $50 \mu \mathrm{l}(100 \mathrm{ng}$ of genomic DNA, $20 \mathrm{pmol}$ of each primer, $200 \mu M$ each of the four dNTPs, $1.5 \mathrm{mM} \mathrm{MgCl}$, $50 \mathrm{mM} \mathrm{KCl}$ and $10 \mathrm{~m} M$ Tris- $\mathrm{HCl}, \mathrm{pH} 8.4$, and 2.5 units of Taq DNA polymerase). The reactions were denatured at $94^{\circ} \mathrm{C}$ for $1 \mathrm{~min}$, annealed at $64^{\circ} \mathrm{C}$ for $1 \mathrm{~min}$ and extended at $72^{\circ} \mathrm{C}$ for $30 \mathrm{~s}$ over 50 cycles with a final extension time of $10 \mathrm{~min}$ at $72^{\circ} \mathrm{C}$. Amplified PCR products $(5 \mu \mathrm{l})$ were digested with the restriction enzyme $K s p \mathrm{I}$, then separated by electrophoresis on a $10 \%$ polyacrylamide gel and detected by silver staining.

\section{Statistical Analysis}

Allele frequencies were calculated from genotype frequencies, and the correlation between the genetic marker and essential hypertension was analyzed by a $\chi^{2}$ test. For the (TTTTA) $)_{n}$ repeat polymorphism with more than two alleles, the statistical significance of the association between the genetic marker and essential hypertension was estimated with a Monte Carlo simulation using the Clump (version 1.6) program [15]. The polymorphism information content was 
Table 2. Comparison of plasma $\mathrm{Lp}(\mathrm{a})$ levels in the indicated genotypes of the (TTTTA) $)_{n}$ repeat polymorphism in normotensive and hypertensive subjects

\begin{tabular}{lll}
\hline Genotype & \multicolumn{2}{l}{ Plasma Lp(a), mg/dl } \\
\cline { 2 - 3 } & $\begin{array}{l}\text { normotensive } \\
\text { subjects }\end{array}$ & $\begin{array}{l}\text { hypertensive } \\
\text { subjects }\end{array}$ \\
\hline $8 / 5$ & $24.9 \pm 12.3(4)$ & $24.8 \pm 5.5(4)$ \\
$8 / 6$ & $16.4 \pm 0.0(1)$ & $0.0 \pm 0.0(0)$ \\
$8 / 8$ & $16.3 \pm 12.8(60)$ & $20.2 \pm 14.6(34)$ \\
$9 / 8$ & $17.7 \pm 17.3(33)$ & $13.9 \pm 6.6(15)$ \\
$9 / 9$ & $12.3 \pm 7.7(8)$ & $9.6 \pm 6.3(3)$ \\
$10 / 8$ & $8.0 \pm 0.0(1)$ & $0.0 \pm 0.0(0)$ \\
$10 / 9$ & $0.0 \pm 0.0(0)$ & $18.4 \pm 0.0(1)$ \\
\hline
\end{tabular}

Values are means \pm SD. Figures in parentheses show the number of subjects. There were no statistically significant differences in plasma Lp(a) levels across the genotypes in either group (Kruskal-Wallis test: $p=0.5170$ for normotensive subjects, $p=0.1090$ for subjects with essential hypertension). estimated using the method of Botstein et al. [16]. The relative risk of essential hypertension associated with allelic variation was expressed in terms of an odds ratio with a $95 \%$ confidence interval. Comparison of the variables across genotypes was performed using a nonparametric Mann-Whitney U test or a Kruskal-Wallis test. All statistical analyses were performed using the SPSSWIN (version 8.0) software package.

\section{Results}

\section{Subjects}

The age distribution of normotensives $(56.4 \pm 9.6$ years) and essential hypertensives (61.6 \pm 9.2 years) differed significantly. The body mass index was not significantly different between normotensives $(23.4 \pm 2.3)$ and essential hypertensives $(24.1 \pm 2.6)$. The ratio of males to females was statistically similar (for normotensives, the ratio of males to females was $1: 1$; for essential hypertensives, it was 45/29).

\section{Plasma Lp(a) Levels}

The mean value of $\mathrm{Lp}(\mathrm{a})$ levels in plasma was $16.1 \pm$ $13.4 \mathrm{mg} / \mathrm{dl}$ in 121 normotensive subjects and $17.8 \pm$ $12.3 \mathrm{mg} / \mathrm{dl}$ in 60 subjects with essential hypertension. Although plasma Lp(a) levels were slightly higher in essential hypertensive subjects than in normotensive subjects, this difference was not statistically significant.

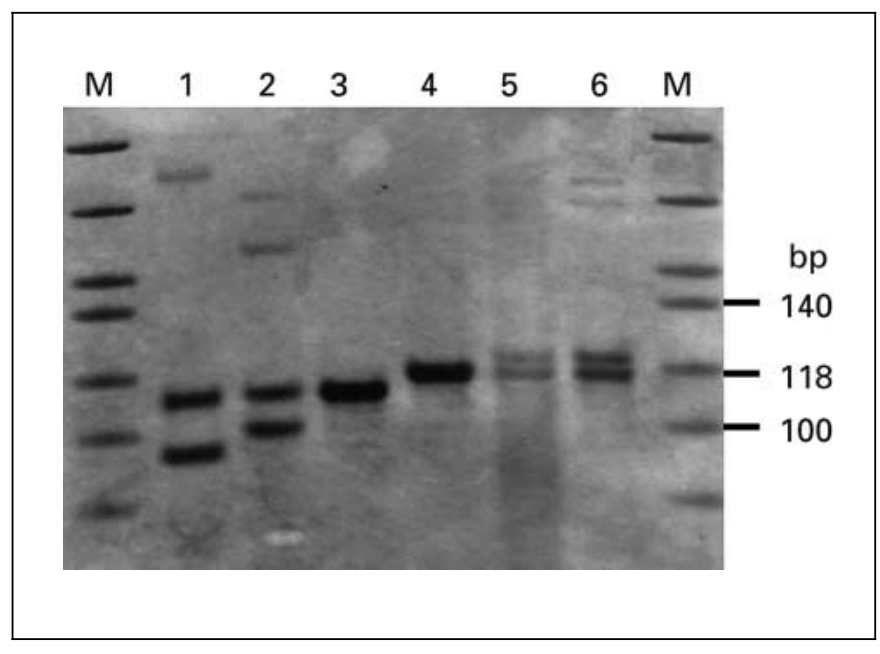

Fig. 1. Electrophoretic patterns of (TTTTA) $)_{\mathrm{n}}$ polymorphisms of the Apo(a) gene. Lane 1: 8/5 repeat; lane 2: 8/6 repeat; lane 3: 8/8 repeat; lane 4: 9/9 repeat; lanes 5 and 6: 10/9 repeat; M: size marker (phi $\mathrm{X}-174$ HinfI).

\section{(TTTTA $)_{n}$ Repeat Polymorphism}

Figure 1 shows the patterns of the (TTTTA) $)_{n}$ repeat polymorphism of the Apo (a) gene revealed by PCR. Overall, five different alleles were detected, with $5,6,8,9$ or 10 repeats corresponding to the PCR product of 93-118 bp. The genotype and allele frequencies of the (TTTTA) repeat polymorphism are given in table 1 . Homozygote $8 / 8$ subjects were most frequently identified among both the normotensive subjects and subjects with essential hypertension. The second most frequent genotype was the $9 / 8$ heterozygote. Other genotypes occurred at frequencies of less than $6 \%$. The allele with 6 repeats was observed only among the normotensive subjects. Heterozygosity was 0.39 and 0.34 for the normotensive and essential hypertensive subjects, respectively, and the polymorphism information content was 0.34 and 0.30 , respectively. There were no significant differences in allele and genotype frequencies between the two groups (Monte Carlo simulation, $\mathrm{p}>0.05, \mathrm{n}=10,000)$. Plasma $\mathrm{Lp}(\mathrm{a})$ levels for the various genotypes of the $A p o(a)$ (TTTTA) repeat polymorphism are given in table 2 . For this polymorphism, there were no significant differences in plasma $\mathrm{Lp}(\mathrm{a})$ levels across the genotypes in either group (KruskalWallis test, $\mathrm{p}>0.05$ ). 


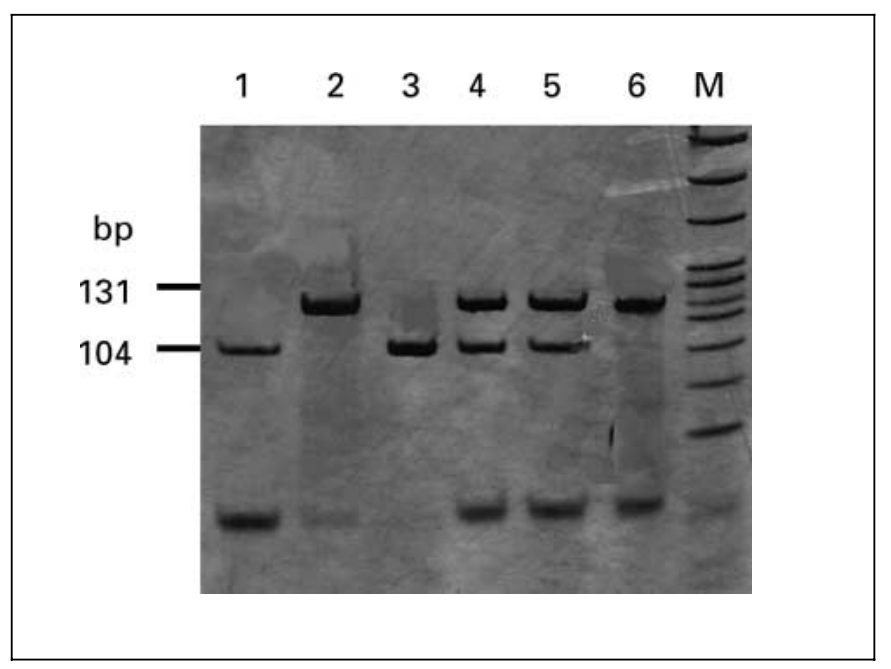

Fig. 2. The electrophoretic patterns of the Met/Thr polymorphism of the Apo (a) gene. Lanes 1 and 3: Thr/Thr homozygotes; lanes 2 and 6: Met/Met homozygotes; lanes 4 and 5: Met/Thr heterozygotes; M: size marker.

\section{Met/Thr Polymorphism}

The patterns of the Met/Thr polymorphism produced by this technique are displayed in figure 2 . In the Thrcoding allele containing the ACG codon, the PCR product is cleaved into 105- and 26-bp fragments by KspI. The Met-coding allele containing the ATG codon remains uncleaved (131 bp). Table 3 shows the genotype and allele distributions of the Met/Thr polymorphism of the $\operatorname{Apo}(a)$ gene. Heterozygosity was 0.48 and 0.47 for the normotensive subjects and subjects with essential hypertension, respectively, and the polymorphism information content was 0.38 and 0.37 , respectively. There were no significant differences in allele and genotype frequencies between the two groups $\left(\chi^{2}\right.$ test, $\left.p>0.05\right)$. Plasma Lp(a) levels for the various genotypes of the $A p o(a)$ Met/Thr polymorphism are given in table 4 . Like the (TTTTA) $)_{n}$ repeat polymorphism, this polymorphism also did not show any significant differences in the plasma $\mathrm{Lp}$ (a) levels across the genotypes in either group (Kruskal-Wallis test, $\mathrm{p}>0.05$ ).

Table 3. Genotype and allele frequencies for the Met/Thr polymorphism of the $A p o(a)$ gene in normotensive and hypertensive subjects

\begin{tabular}{|c|c|c|c|c|c|c|c|}
\hline & \multicolumn{3}{|l|}{ Genotype } & \multicolumn{2}{|l|}{ Allele } & \multirow[t]{2}{*}{$\mathrm{H}$} & \multirow[t]{2}{*}{ PIC } \\
\hline & Met/Met & Met/Thr & Thr/Thr & Met & Thr & & \\
\hline Normotensive subjects & $54(26)$ & $140(67)$ & $14(7)$ & $248(60)$ & $168(40)$ & 0.4815 & 0.3656 \\
\hline Hypertensive subjects & $20(28)$ & $47(66)$ & $4(6)$ & $87(61)$ & $55(39)$ & 0.4746 & 0.3620 \\
\hline$\chi^{2}$ & & 0.2057 & \multicolumn{5}{|c|}{0.1204} \\
\hline $\mathrm{p}$ & & 0.9023 & \multicolumn{5}{|c|}{0.7286} \\
\hline Odds ratio $(\mathrm{CI})$ & \multicolumn{5}{|c|}{$1.07(0.73-1.58)$} & & \\
\hline
\end{tabular}

Frequency is given as a percentage in parentheses. There were no statistically significant differences in genotype and allele frequencies between normotensive and hypertensive subjects. $\mathrm{H}=$ Heterozygosity; PIC = polymorphism information content; $\mathrm{CI}=95 \%$ confidence interval.

Table 4. Correlation of plasma Lp(a) levels with the Met/Thr polymorphism

\begin{tabular}{llll}
\hline & \multicolumn{2}{l}{ Plasma Lp(a), mg/dl } \\
\cline { 2 - 4 } & Met/Met & Met/Thr & Thr/Thr \\
\hline Normotensive subjects & $18.5 \pm 14.9(34)$ & $15.8 \pm 13.1(76)$ & $11.0 \pm 9.1(11)$ \\
Hypertensive subjects & $16.2 \pm 13.5(16)$ & $18.8 \pm 11.9(41)$ & $13.5 \pm 14.2(3)$
\end{tabular}

Values are given as means \pm SD. Figures in parentheses show the number of subjects. There were no statistically significant differences in plasma Lp(a) levels across the genotypes in either group (Kruskal-Wallis test: $\mathrm{p}=0.2070$ for normotensive subjects, $\mathrm{p}=0.4620$ for subjects with essential hypertension). 


\section{Discussion}

The exact pathogenesis of essential hypertension is unknown. A number of risk factors, including genetic defects, are known to predispose subjects to essential hypertension. Therefore, the identification of genetic risk factors should enhance our understanding of the molecular basis of essential hypertension. Allelic association studies are commonly used to identify the susceptibility genes for complex traits such as essential hypertension [17].

Until now, few data have been reported regarding plasma Lp(a) levels among people with essential hypertension. Some authors have found normal plasma $\mathrm{Lp}(\mathrm{a}) \mathrm{lev}-$ els in these subjects $[18,19]$, whereas others have reported increased plasma Lp(a) levels [20-22]. In the present study, the mean plasma Lp(a) level of subjects with essential hypertension was not significantly different from that of normotensive subjects. This result implies that high plasma $\mathrm{Lp}$ (a) levels may not be an independent risk factor in the etiology of essential hypertension among Koreans. There were no significant differences between normotensive Korean subjects and subjects with essential hypertension in allele or genotype frequencies of the (TTTTA) repeat and Met/Thr polymorphisms of the Apo(a) gene. Furthermore, these two polymorphisms were not significantly associated with plasma $\mathrm{Lp}$ (a) levels in either group of subjects. Therefore, it is unlikely that these polymorphisms are associated with the etiology of essential hypertension among Koreans. Hong et al. [23] reported that the (TTTTA $)_{\mathrm{n}}$ repeat polymorphism of the $A p o(a)$ gene was significantly associated with the plasma $\mathrm{Lp}$ (a) level in a coronary artery disease group, while the Met/Thr poly- morphism was linked with the plasma $\mathrm{Lp}$ (a) level in the control group. Differences in the selection of study subjects may influence the difference in the association between the genetic variations of $A p o(a)$ gene and the plasma Lp(a) level. However, we cannot exclude the possibility that these polymorphisms play a small role in the pathogenesis of this disease, because minor gene effects may be masked in a disease as complex as essential hypertension. Furthermore, the statistical power of retrospective case-control studies can be low when assessing correlations between genetic markers and complex diseases. Therefore, further studies using larger sample sizes are required to understand the influence of the $A p o(a)$ gene on the pathogenesis of essential hypertension.

\section{Conclusion}

To our knowledge, this study is the first report of an investigation of a possible association between the genetic polymorphisms of the $A p o(a)$ gene and essential hypertension in the Korean population. Our results suggest that the (TTTTA) $)_{n}$ repeat and Met/Thr polymorphisms of the $A p o(a)$ gene are not significantly associated with essential hypertension and plasma $\mathrm{Lp}(\mathrm{a})$ levels in Koreans.

\section{Acknowledgments}

Human blood samples were kindly supplied by Dr. Seung Hee Cho, Clinical Pathology, Seoul Hygiene Hospital, Seoul, Korea. This work was supported in part by grants from the Korean Sciences and Engineering Foundation through the Research Center for Cell Differentiation.

\section{References}

1 Utermann G: The mysteries of lipoprotein(a). Science 1989;246:904-910.

2 Berg K: A new serum type system in man: The Lp-system. Acta Pathol Microbiol Scand 1963; 59:369-382.

3 Dahlen GH, Guyton JR, Attar M, Farmer JA, Kautz JA, Gotto AM Jr: Association of levels of lipoprotein Lp(a), plasma lipids, and other lipoproteins with coronary artery disease documented by angiography. Circulation 1986;74: 758-765.

4 Rhoads GG, Dahlen G, Berg K, Morton NE, Dannenberg AL: Lp(a) lipoprotein as a risk factor for myocardial infarction. JAMA 1986;256: 2540-2544.
5 Hoefler G, Harnoncourt F, Paschke E, Mirtl W, Pfeiffer KH, Kostner GM: Lipoprotein $\mathrm{Lp}$ (a). A risk factor for myocardial infarction. Arteriosclerosis 1988;8:398-401.

6 Stein JH, Rosenson RS: Lipoprotein Lp(a) excess and coronary heart disease. Arch Intern Med 1997;96:1390-1397.

7 Danesh J, Collins R, Peto R: Lipoprotein(a) and coronary heart disease. Meta-analysis of prospective studies. Circulation 2000;102: 1082-1085.

8 Boerwinkle E, Leffert CC, Lin J, Lackner C, Chiesa G, Hobbs HH: Apolipoprotein(a) gene accounts for greater than $90 \%$ of the variation in plasma lipoprotein(a) concentrations. J Clin Invest 1992;90:52-60.
9 Kraft HG, Kochl S, Menzel HJ, Sandholzer C, Utermann G: The apolipoprotein(a) gene: A transcribed hypervariable locus controlling plasma lipoprotein(a) concentration. Hum Genet 1992;90:220-230.

10 Trommsdorff M, Kochl S, Lingenhel A, Kronenberg F, Delport R, Vermaak H, Lemming L, Klausen IC, Faergeman O, Utermann G, Kraft HG: A pentanucleotide repeat polymorphism in the $5^{\prime}$ control region of the apolipoprotein(a) gene is associated with lipoprotein(a) plasma concentrations in Caucasians. J Clin Invest 1995;96:150-157. 
11 Park H-Y, Nabika T, Notsu Y, Kobayashi S, Masuda J: Effects of apolipoprotein A gene polymorphism on lipoprotein(a) concentrations in Japanese. Clin Exp Pharmacol Physiol 1999;26:304-308.

12 Sambrook J, Fritsch EF, Maniatis T: Molecular Cloning. A Laboratory Manual. Cold Spring Harbor, Cold Spring Harbor Laboratory Press, 1989.

13 Mooser V, Mancini FP, Bopp S, PethoSchramm A, Guerra R, Boerwinkle E, Müller $\mathrm{HJ}$, Hobbs HH: Sequence polymorphisms in the $\operatorname{apo}(a)$ gene associated with specific levels of Lp(a) in plasma. Hum Mol Genet 1995;4 173-181.

14 Kraft HG, Haibach C, Lingenhel A, Brunner C, Trommsdorff M, Kronenberg F, Müller HJ, Utermann G: Sequence polymorphism in kringle IV 37 in linkage disequilibrium with the apolipoprotein(a) size polymorphism. Hum Genet 1995;95:275-282.
15 Sham PC, Curtis D: Monte Carlo tests for associations between disease and alleles at highly polymorphic loci. Ann Hum Genet 1995;59: 97-105.

16 Botstein D, White RL, Skolnick M, Davis RW: Construction of a genetic linkage map in man using restriction fragment length polymorphisms. Am J Hum Genet 1980;32:314-331.

17 Lander ES, Schork NJ: Genetic dissection of complex traits. Science 1994;265:2037-2048.

18 Pedrinelli R, Giampietro O, Carmassi F, Melillo E, Dell'Omo G, Catapano G, Matteucci E, Talarico L, Morale M, De Negri F, et al: Microalbuminuria and endothelial dysfunction in essential hypertension. Lancet 1994;344:1418.

19 Flesch M, Sachinidis A, Ko YD, Kraft K, Vetter H: Plasma lipids and lipoproteins and essential hypertension. Clin Investig 1994;72: 944-950.
20 Donders SH, Lustermans FA, van Wersch JW: Fibrinolysis factors and lipid composition of the blood in treated and untreated hypertensive patients. Blood Coagul Fibrinolysis 1992; 3:61-67.

21 Donders SH, Lustermans FA, van Wersch JW: Low order correlations of lipoprotein(a) with other blood lipids and with coagulation and fibrinolysis parameters in hypertensive and diabetic patients. Blood Coagul Fibrinolysis 1992;3:249-256.

22 van Wersch JW: The behaviour of lipoprotein(a) in patients with various diseases. Scand J Clin Lab Invest 1994;54:559-562.

23 Hong SH, Min WK, Cheon SL, Lee CC, Song J, Kim JQ: Association between apolipoprotein(a) polymorphism and $\mathrm{Lp}$ (a) levels in Koreans. Mol Cells 1998;8:544-549. 